\title{
Barite Veins in the Benue Trough: Field Characteristics, the Quality Issue and Some Tectonic Implications
}

\author{
Michael I. Oden ${ }^{1}$ \\ ${ }^{1}$ Department of Geology, University of Calabar, P.M.B. 1115, Calabar, Cross River State, Nigeria \\ Correspondence: Michael I. Oden, Department of Geology, University of Calabar, P.M.B. 1115, Calabar, Cross \\ River State, Nigeria. Tel: 234-803-677-3902. E-mail: odenmi@yahoo.com
}

Received: February 24, 2012 Accepted: March 30, 2012 Online Published: June 1, 2012

doi:10.5539/enrr.v2n2p21 URL: http://dx.doi.org/10.5539/enrr.v2n2p21

\begin{abstract}
The Benue trough is Nigeria's main, but not exclusive source of barite mineralisation. There are at least ten barite fields in the trough, each containing swarms of veins or concordant stratiform minerals flats of hydrothermal origin. There are only two vein trends in the trough: the NW-SE trend, which tends to be orthogonal to the axis of the trough; and the N-S to NNE-SSW trend, which is younger than the former. Both vein sets are formed from ac tension joints reflecting different post-sedimentary deformation phases in the trough. The NW-SE veins are also more frequent than the N-S veins, almost in the ration of 2:1. Although 86 veins have been studied, not one was found oriented parallel to the axis of the trough, a good indication of structural control on mineral vein orientations. The dips of the veins tend to be high $\left(>80^{\circ}\right)$, a condition that favours manual mining. Veins tend to display a simple block profile and their widths vary from a few centimetres to as much as $6 \mathrm{~m}$, though the most frequently occurring widths are between $50 \mathrm{~cm}$ and $1 \mathrm{~m}$. The implication of this is that $\mathrm{BaSO}_{4}$ concentrations in hydrothermal fluids in the trough were probably low during the Cretaceous period. In many veins, there is barite quality contrast between the top part and the lower portions. Higher quality barite tends to come from the lower portions. Hence it is expected that much of the low quality stigma associated with Nigerian barite from the trough would be relieved when mining gets down to good depths. For this reason, mining in those veins of low quality barite should proceed by vertical stripping.
\end{abstract}

Keywords: Benue Trough, Barite veins, Azara fields, sandstones, extension joints, crack-seal mechanism

\section{Introduction}

Earlier literature on the Nigerian barite mentions the mineral as a gangue in galena and sphalerite veins (Farrington, 1952; McConnel, 1949b). But as from 1951, the barite resource of Nigeria started gaining recognition. Bogue (1951) gave a report of a barite prospect near Gabu in Ogoja Province (now in Cross River State). In 1957 the "Minerals and Industry in Nigeria" yearbook reported barite occurrences at Lefin in Ogoja Province; Aba-Gbandi, Keana and Akiri in Benue Province and Dumgel in Adamawa Province.

Tate (1959) gave a reserve estimate of 40,000 tonnes to a depth of $20 \mathrm{~m}$ in the Azara barite locality, while Offodile (1976) listed barite occurrences at and analysed samples from Azara, Gbande, Chiata, Keana and Ibi, all in the Middle Benue Trough. He also produced a small scale map of the Azara-Akiri-Wuse area, showing some barite veins as well as physical and chemical properties of samples from all those locations.

Between January 1978 and December 1979, staff of Nigerian Mining Corporation (NMC) carried out a semi-detailed reserve study of five out of the eighteen veins of the Azara field (ML 18706). They indicated a reserve of 730,000 tonnes of barite, with an average specific gravity of 3.64, down to 30m depth. Vein 17 was found to be the most promising. Only vein 1 was drilled with a diamond core drill in this investigation and this gave a reserve of 30,000 tonnes to a depth of $10.0 \mathrm{~m}$.

In 1987, the "Minerals and Industry in Nigeria" yearbook listed the following barite occurrences: Lefin in Cross River State; Aloshi, Akiri, Wuse, Keana, Azara and Gbande in Plateau State; as well as Ibi and Dumgel in Gongola State. Staff of NMC in 1998, working again in the Azara field, reported a reserve of 71,655 tonnes from a comprehensive diamond drilling and trenching programme of only the eastern part of Vein 17 (ML 18706). The specific gravity values of the samples recovered ranged from 3.35 to 4.24 .

In 2005, the company Tashbond Limited produced a feasibility report for accelerated production of barite and bentonite. This work, which was commissioned by the Ministry of Solid Minerals Development (MSMD), Abuja, 
contains some fairly good quality information on deposits or prospects, geological background, short term production strategies and issues that affect barite production in Nigeria generally.

Also in 2005, under the auspices of the Sustainable Management of Mineral Resources project of the ministry (MSMD), a geophysical firm was engaged to look more carefully at Gabu-Osina-Alifokpa prospect in Cross River State. Using conductivity and gravity profiling, the firm delineated a number of barite veins in that field, although nothing concrete was done regarding reserve estimation.

In a country-by-country survey of activities in the solid mineral sector, the journal "Industrial Mineral" commented thus about Nigerian barite in 1996: ".......the quality of the material is not often up to API specifications, and requires blending from imported sources....."

Also Hoque and Nwajide (1984), in a presentation of the tectono-sedimentological evolution of the Benue Trough, averred that the mineralised veins had axis-parallel trends in conformity with the fold axes, major faults and gravity anomalies.

This paper presents some of the research carried out on Nigerian barite in the Benue Trough recently, from field characteristics, through the quality issue to some aspects of the tectonics of the trough. By means of these field data, it also evaluates the claims that have been made for and against this commodity in Nigeria.

\section{Results}

\subsection{Field Characteristics}

\subsubsection{Types of Occurrence}

Only two types of barite occurrences have been seen in the field. These are:

The sediment-hosted, stratiform, concordant type or "mineral flat" (Fyfe et al., 1978). This type of occurrence is very much less frequent and has so far been seen in Alifokpa (Cross River State) and Gidanwaya in Ibi (Taraba State), only. It is hydrothermal in origin, lensoid in shape and is frequently multilayered.

The discordant, vein type of occurrence. This is by far ( $>90 \%)$ the most common occurrence and veins range in width from $20 \mathrm{~cm}$ to $6 \mathrm{~m}$. Some of the most impressive barite veins are veins 1 and 17 in Azara area (ML 18706) Figure 1a and Figure 1b; Aloshi main vein, with a barite width of about $60 \mathrm{~cm}$ sandwiched by microcrystalline quartz and a length of about $8 \mathrm{~km}$ (Figure 2); as well as the Gabu-Osina mother vein, with a known width of about $6 \mathrm{~m}$ and a length of over $2 \mathrm{~km}$ (Figure 3 ).

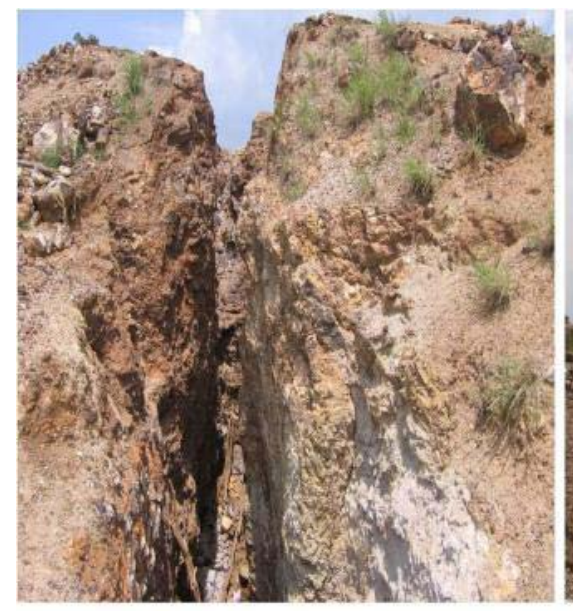

A

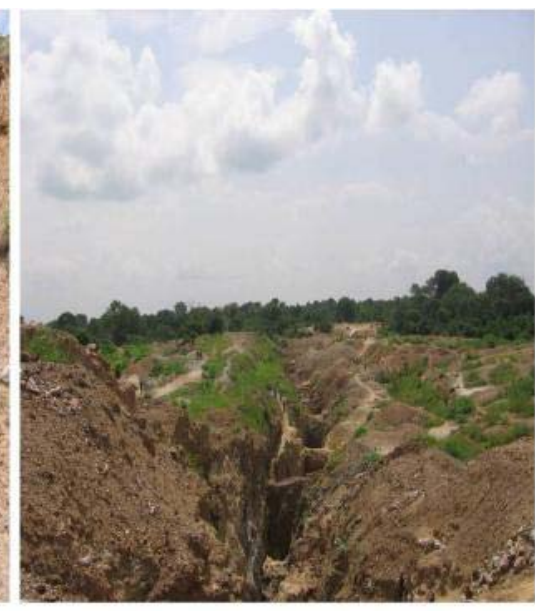

B

Figure 1. Veinstein 17, ML 19706, Azara, A-Looking east and B-Looking west.

This is the most prominent barite vein in Azara area 


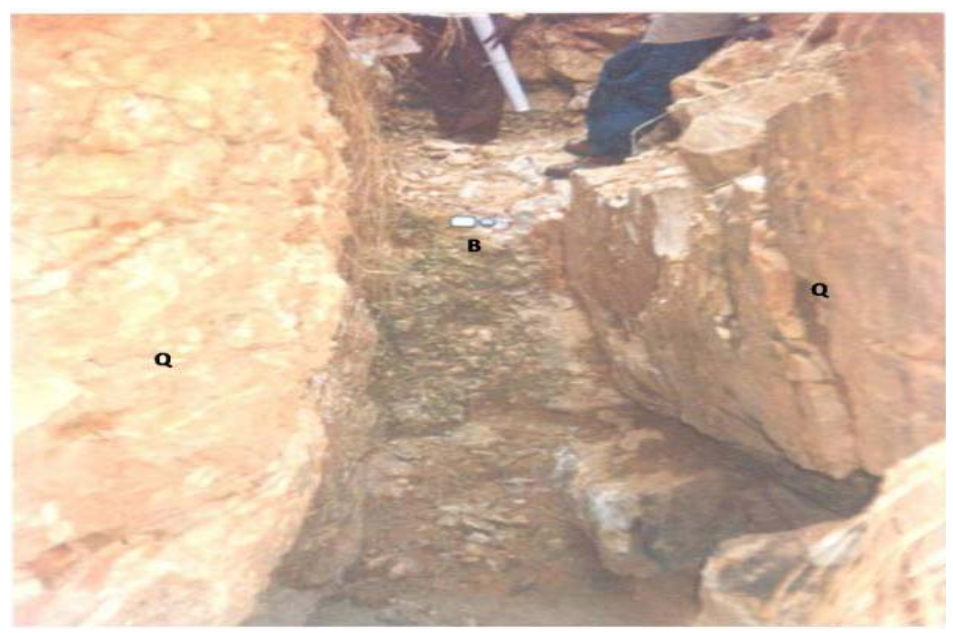

Figure 2. Aloshi main vein, where the barite B is sandwiched between microcrystalline quartz $\mathrm{Q}$.

Barite is $60 \mathrm{~cm}$ wide and has a block profile

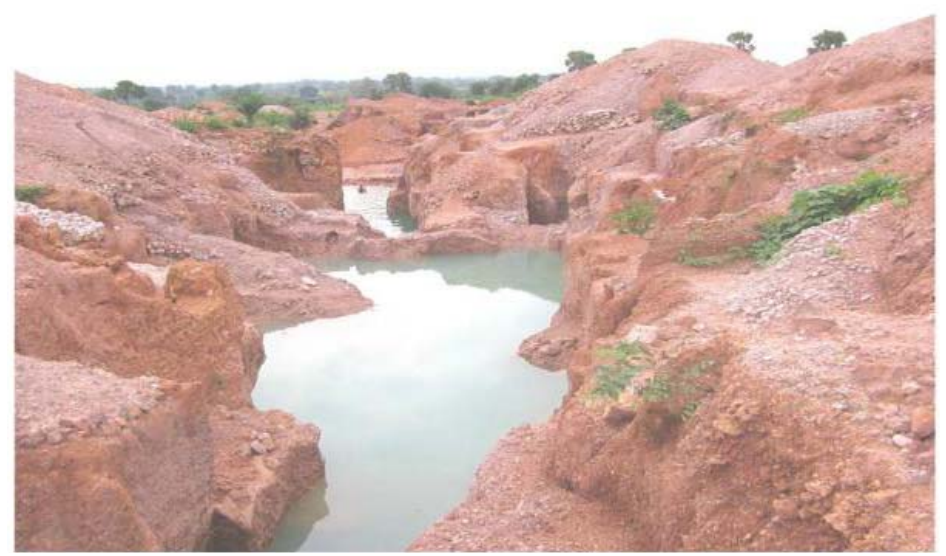

Figure 3. Gabu-Osina monther vein, a $6 \mathrm{~m}$ wide barite vein of very high quality, is one of the most majestic in the Benue Trough

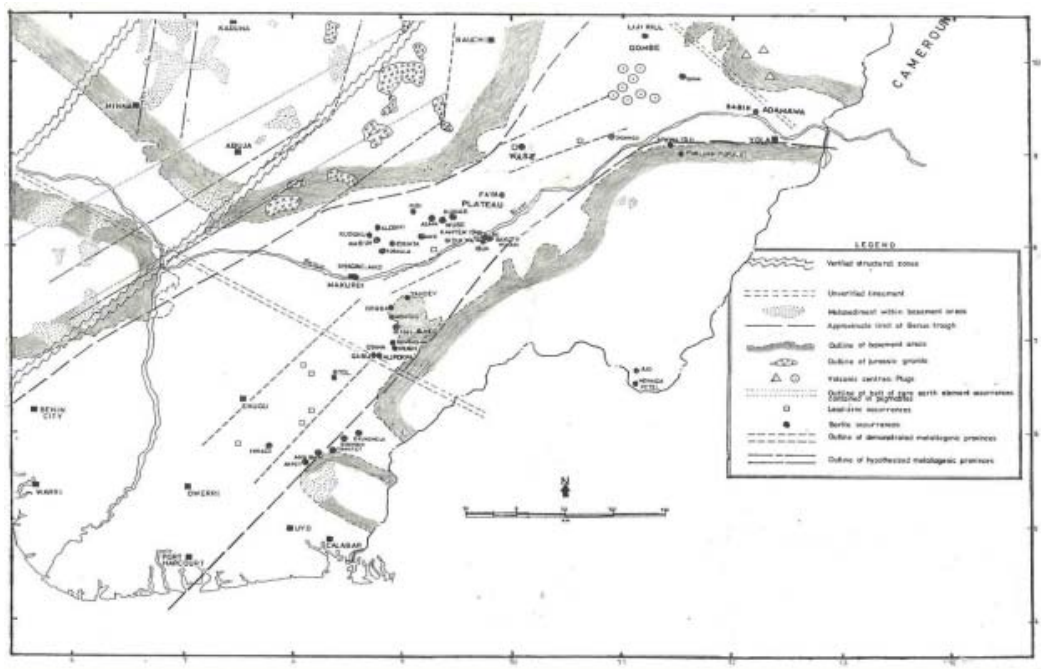

Figure 4. Map of the eastern part of Nigeria, showing the Benue Trough and mineral locations so far known(Modified from NIMAMOP map, all locations of mines fixed by GPS) 


\subsubsection{Host Rocks}

The host rocks range from sandstones (Figure 5), siltstones, shales and mudstones of the Cretaceous period, to concretionary ironstones derived from them. These are by far the most consistent rock types that host barites in the trough. In addition to these, basement gneisses have been observed to host barite at Lessel Mbato, near Gboko (Figure 6). Edu, (2006) also observed basement gneisses, porphyritic and fine grained granite hosting barite in parts of Taraba State, also in the trough. The persistence of barite veins into the basement complex below the Cretaceous cover is an indication not only of how deep the veins are, but more importantly, how thick-skinned the Cretaceous deformation was that produced the joints initially

\subsection{Barite Occurrences}

Currently, occurrences of barite are found in eight states within the Benue Trough. These are: Adamawa, Benue, Cross River, Ebonyi, Gombe, Nasarawa, Taraba and Plateau. But the major producing states are only Benue, Cross River, Nasarawa and Taraba (Table 1).

Table 1. Barite mineral resource of the Benue Trough, showing host communities and states as well as current status and required activities. * Major producing states

\begin{tabular}{|c|c|c|c|c|c|}
\hline $\mathrm{S} / \mathrm{N}$ & STATE & LOCATIONS & $\begin{array}{l}\text { RESERVE } \\
\text { ESTIMATION } \\
\text { (TONNES) }\end{array}$ & STATUS & REMARK \\
\hline 1 & Nasarawa* & $\begin{array}{l}\text { Azara, Akiri, Aloshi, Chiata } \\
\text { Gidan Bera, Gidan Tailor, } \\
\text { Wuse Kuduku, Ribi. }\end{array}$ & $\begin{array}{l}\text { 730,000 recorded by } \\
\text { NMC at Azara, } \\
\text { Akiri and Wuse } \\
\text { alone ( } 5 \text { veins })\end{array}$ & $\begin{array}{l}\text { Mining in progress } \\
\text { by private companies } \\
\text { and artisanal miners. } \\
\text { NMC has divested }\end{array}$ & $\begin{array}{l}\text { Very rich state, } \\
\text { grade ranges from } \\
\text { poor to good, } \\
\text { reserve could } \\
\text { improve through } \\
\text { further } \\
\text { exploration }\end{array}$ \\
\hline 2 & Plateau & Panyam (Wase), Faya & $\begin{array}{l}\text { Yet to be } \\
\text { determined }\end{array}$ & $\begin{array}{c}\text { Registered } \\
\text { companies and } \\
\text { artisanal miners at } \\
\text { work }\end{array}$ & $\begin{array}{l}\text { Further } \\
\text { exploration could } \\
\text { increase stock of } \\
\text { veins }\end{array}$ \\
\hline 3 & Taraba* & $\begin{array}{c}\text { Mbanga Petel, Mbanga } 3 \\
\text { corner, Juo, Gidan Waya, } \\
\text { Kauyen Isa, Bakuyu, Ibua, } \\
\text { Kumar, Pupule, Apawa } 1 \& \\
\text { 2, Didango, Suwa }\end{array}$ & $\begin{array}{l}\text { Yet to be } \\
\text { determined }\end{array}$ & $\begin{array}{l}\text { Active informal and } \\
\text { some organized } \\
\text { mining in progress }\end{array}$ & $\begin{array}{l}\text { Further } \\
\text { exploration } \\
\text { necessary to } \\
\text { improve the } \\
\text { known stock of } \\
\text { veins and boost } \\
\text { reserve }\end{array}$ \\
\hline 4 & Benue* & $\begin{array}{c}\text { Ambua, Torkula, Makurdi, } \\
\text { Kaseyo, Yandev, Orgba, } \\
\text { Ihugh, Konshisha, Lessel, } \\
\text { Tombu, Kornya, Iye, } \\
\text { Zanzan, Logo }\end{array}$ & $\begin{array}{l}\text { Yet to be } \\
\text { determined }\end{array}$ & $\begin{array}{c}\text { Active informal and } \\
\text { organized mining in } \\
\text { progress }\end{array}$ & $\begin{array}{l}\text { Detailed } \\
\text { exploration work } \\
\text { necessary to } \\
\text { improve the } \\
\text { known stock of } \\
\text { veins and boost } \\
\text { reserve }\end{array}$ \\
\hline 5 & Adamawa & Ganye, Suwa, Sabin village & $\begin{array}{l}\text { Yet to be } \\
\text { determined }\end{array}$ & $\begin{array}{c}\text { Only Suwa and Sabin } \\
\text { deposits are currently } \\
\text { mined }\end{array}$ & $\begin{array}{l}\text { Further } \\
\text { exploration } \\
\text { necessary }\end{array}$ \\
\hline 6 & Cross River* & $\begin{array}{l}\text { Alifokpa, Gabu, Osina, } \\
\text { Alesi, Ekpokpa, Edondon, } \\
\text { Iyamitet, Ndam, Okokori, } \\
\text { Okumurutet, Okangha, Agoi } \\
\text { Ekpo, Agoi Ibami, Akpet 1, } \\
\text { Akpet Central, Okurike, } \\
\text { Lefin, Bitol, Ugbem }\end{array}$ & $\begin{array}{l}\text { Yet to be } \\
\text { determined }\end{array}$ & $\begin{array}{l}\text { Enormous informal } \\
\text { and organised mining } \\
\text { in progress }\end{array}$ & $\begin{array}{l}\text { Large scale } \\
\text { operators needed } \\
\text { and further } \\
\text { exploration work } \\
\text { very necessary in } \\
\text { this state with the } \\
\text { highest prospect }\end{array}$ \\
\hline 7 & Gombe & Liji Hill, Gombe town & $\begin{array}{l}\text { Yet to be } \\
\text { determined }\end{array}$ & $\begin{array}{l}\text { Mining activity } \\
\text { started here recently }\end{array}$ & $\begin{array}{l}\text { Requires further } \\
\text { exploration }\end{array}$ \\
\hline 8 & Ebonyi & Ishiagu & $\begin{array}{l}\text { Yet to be } \\
\text { determined }\end{array}$ & $\begin{array}{l}\text { No mining activity is } \\
\text { going on }\end{array}$ & $\begin{array}{l}\text { Requires further } \\
\text { exploration. }\end{array}$ \\
\hline
\end{tabular}




\subsection{Barite Fields}

These fields are delineated based on availability of an optimum number of veins for large scale operations.

I. Azara field in Nasarawa state: including Azara, Ribi, Wuse and Akiri (Figure. 4). This field has a large number of veins (over 20), although quality of material is generally low, except at Ribi. It also includes the well know ML18706 of the former Nigerian Mining Corporation, which alone contains 18 barite veins, and is currently held by EMO Ashapura Energy and Mining Ltd.

II. Keana field in Nasarawa state: including Aloshi, Ambua, Chiata, Kuduku, etc. Accessibility constitutes a major problem to the development of this field, for which reason, many of the veins lie abandoned and there is no impetus for exploration of new veins.

III. Guma field in Benue State: this is made up of Torkula, Kaseyo, Zanzan, Iye, etc to which the veins in the University of Agriculture campus, at Makurdi can be added. The highest concentration of barite veins in this field is within and around Torkula and because of its size, this field holds a lot of promise, even though its known veins are currently fewer than in Azara field.

IV. Lessel field in Benue State: this is another large field in terms of number of veins and occurs mainly south of Gboko, although the Yandev deposit north of Gboko, can also be added to this field. Included in this field are Lessel Bunde, Lessel Mbato and Lessel Mbagwa, with over 20 veins currently in production.

V. Didango field in Karim Lamido, Taraba State: only one major vein is known so far in this field. It is at least $1.5 \mathrm{~m}$ wide and possibly up to $2 \mathrm{~km}$ in length, trending approximately $\mathrm{N} 130 \mathrm{o}$. The main disadvantages this site has are high galena association with barite as well as very difficult terrain which makes accessibility a big problem.

VI. Ibi field in Ibi Local Government Area of Taraba State: this field contains deposits at Gidan Waya, Kauyen Isa, Bakuyu and Ibua. Apart from Gidan Waya which has stratiform and conformable mineral flats, the other deposits are all veins. At Bukuyu village, veins of $2.0 \mathrm{~cm}$ to $8.0 \mathrm{~cm}$ width stretch for $5 \mathrm{~km}$ to $6 \mathrm{~km}$ (Edu, 2006).

VII. Yala field in northern Cross River: this field contains the Gabu-Osina-Alifokpa prospect, which contains what is perceived to be the single largest barite vein in Nigeria, occurring between Gabu and Osina. It is thought by miners to be up to $6 \mathrm{~m}$ wide, although after eight years of excavation, mining is still at the elluvial stage. This vein probably extends across the border into nearby Benue State and at that; it should be over $2 \mathrm{~km}$ long. The Alifokpa mine is part of a series of stratiform mineral flats. This field contains barite deposits in Lefin and Bitol. While Bitol is a relatively new find, Lefin has been officially associated with barite occurrence since 1957 (Minerals and Industry in Nigeria, 1957).

VIII. Gombe field in Gombe State: this is a newly discovered field located some $2 \mathrm{~km}$ form Gombe town. About 10 barite veins are worked around Liji Hill by three companies and the prospects of discovering new veins around there are quite good.

IX. Kumar field in Taraba State: this has a swarm of veins (up to 40 in number) and new ones are still being added. The quality of the barite is generally good; the main drawback here is access to Kumar Village in Ibi Local Government Area of Taraba State, especially during the wet season. The combination of number of veins and good quality of the material makes this field a good prospect.

$\mathrm{X}$. Ihugh field in Benue State: this is a relatively new field, occurring in southern Benue state and containing more than twenty discrete workings at their early stages. The quality of the material for now may not be high because of the relatively near-surface level of the workings.

Table 2. Barite deposits and associated qualities or grade

\begin{tabular}{lll}
\hline Low quality (SG: 3.6-4.0) & Medium quality (SG: 4.0-4.2) & High quality (SG: above 4.2) \\
\hline Aloshi & Ribi & Ibi \\
& Ambua & Alifokpa \\
& Yandev & Gabu \\
Azara & Lessel & Osina \\
Wuse & Kornya & Konshisha \\
& & Didango \\
Kuduku & & Kumar \\
Pupule & & \\
Apawa & Kumar & \\
Tombu & Ihugh & \\
Bunde Lessel & Orgba & \\
\hline
\end{tabular}


There are barite occurrences outside the Benue Trough and Table 1 is a summary of the entire current position of barites mining activities in the trough. Table 2 shows the quality of barites that comes from some of the different localities or deposits in the trough. Consistently every "ROM" delivery from Aloshi, Azara, Wuse, mines must be beneficiated and then blended with materials from other mines to deliver a useful batch (of API grade). On the other hand deliveries from Ibi, Alifokpa, Gabu, Osina, Kumar, Konshisha, Didango mines tend to have high specific gravities (above 4.2) and as such are useful for blending to upgrade the lower grade materials. This scenario ensures Nigeria does not actually need to import high grade barite from foreign countries. Altogether there are more mines producing above - API grade materials than those producing below API-grade barite. Whatever grade of barite that is required in Nigeria, it can actually be produced locally.

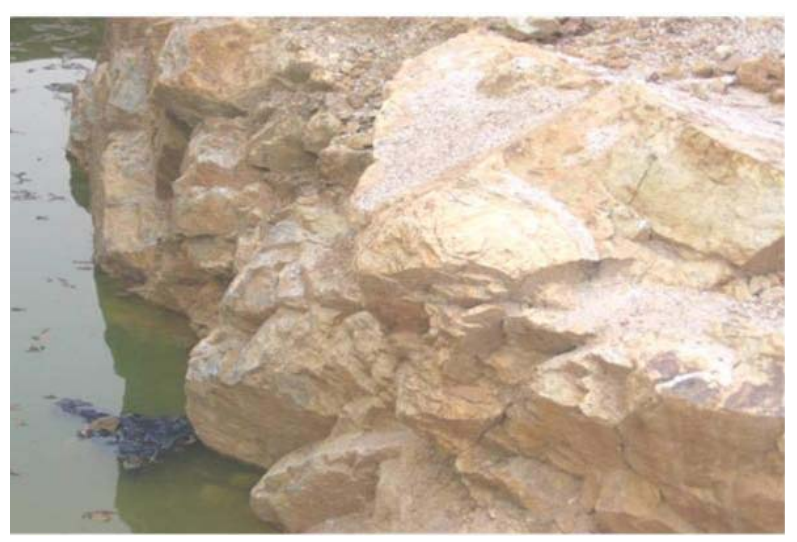

Figure 5. Sandstones are very common host rocks to the barite veins throughout the trough

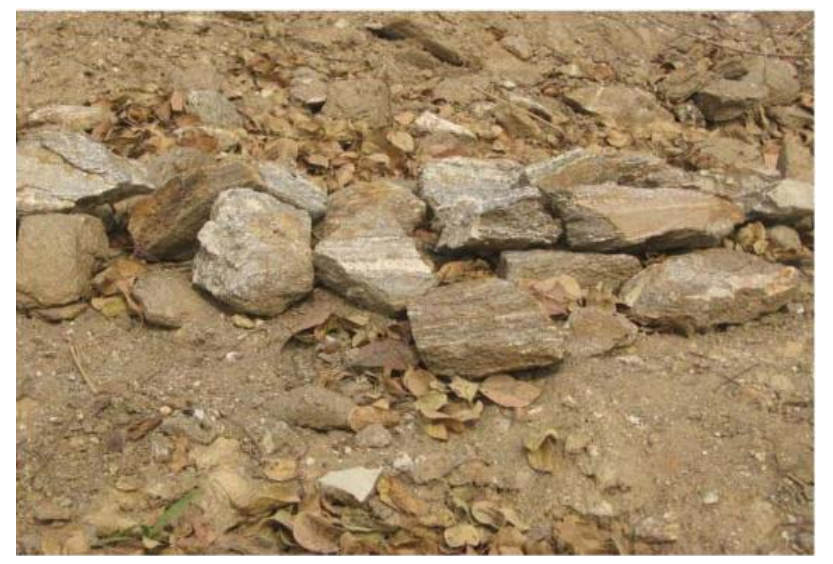

Figure 6. Barite mining at Lessel Mbatoo has gone past Cretaceous host rocks into basement gneisses

\subsection{Attitude of Barite Veins}

\subsubsection{Vein Persistence}

Barite veins in the Benue Trough tend to be persistent, even if discontinuously so. The best examples are the Aloshi main vein (Figure 2), Azara Vein 17 (Figure1a and Figure1b) and Gabu-Osina mother vein (Figure 3). The Aloshi vein has been traced discontinuously for up to $8 \mathrm{~km}$, while a section of the Gabu-Osina vein has been traced geographically for up to $2 \mathrm{~km}$. On the other hand, Vein 17 has indicated a length in excess of $1 \mathrm{~km}$, from a large scale map of the area produced by NMC in 1998. In Taraba State, vein lengths of over $2 \mathrm{~km}$ have been estimated for deposits at Juo (Sardauna LGA), Bakuyu village (Ibi LGA) and Didango in Karim Lamido LGA (Edu, 2006).

\subsubsection{Vein Trends}

The trends of barite veins in the Benue Trough are best illustrated by Figure 7. This is a rose diagram showing the orientations of 86 barite veins in the trough. The most prominent mineral vein trend is that in the NW-SE 
quadrants, orthogonal or nearly so, to the axis of the Benue Trough $\left(\mathrm{N} 65^{\circ} \mathrm{E}\right.$, Benkhelil, 1981). This trend accommodates about $66 \%$ of all measurements. Approximately $34 \%$ of all measurements are oriented in the N-S corridor, between $\mathrm{N} 20^{\circ} \mathrm{W}$ and $\mathrm{N} 20^{\circ} \mathrm{E}$, which is the second trend of the veins. It is interesting that the axis of the trough (BTA) is itself not a favoured vein orientation direction, contrary to what Hoque and Nwajide (1984) averred. It is also interesting that the population of mineral veins of approximately N-S orientation, obviously belonging to another phase of deformation, is far less than those that tend to be orthogonal to axis of the trough. There is therefore tight structural control on vein orientations.

The dips of barite veins tend to be high (Figure 2, Figure 8, and Figure 9), of the order of $80^{\circ}$ to $90^{\circ}$, a condition that favours manual mining. Low angle veins are problematic to artisanal miners since they have to continue to strip the overburden to keep their operations on the surface. They also seem to result in more extensive damage to the environment when mined, than vertical veins.

Also noteworthy is the presence of small scale fracturing (brecciation) and secondary mineralisation in many, but not all the barite veins. Brecciation and neomineralisation are particularly noticeable at Azara, Wuse, Akiri and Aloshi, all in Nasarawa state. The very brittle barite veins and host rocks in these areas are randomly fractured, while secondary minerals like quartz, feldspar, hematite, siderite, and limonite fill the fractures to act as binding cement. This is partly responsible for the low quality of barite from such sources as Akiri, Aloshi, Azara, Wuse, etc.

\subsubsection{Vein Structure and Width}

By far the most common vein structure in profile is the vertical block structural type (Figure. 2 and Figure 9). Barite in a vein tends to gather into a block irrespective of the size of the block and these blocks tend to be vertical. This simple structure in profile should make modeling of barite veins in the sub-surface a more accurate exercise, as it makes mining and beneficiation easier.

Individual vein widths in the Benue Trough, on the other hand, vary from as small as a few centimetres to $6 \mathrm{~m}$. As shown in Figure 10, the most frequently occurring vein width, out of 42 measurements, is that between $50 \mathrm{~cm}$ and $1 \mathrm{~m}$. The smaller veins $(0-2 \mathrm{~m})$ are by far more frequently occurring than wide veins $(5-6 \mathrm{~m})$. This has fluid pressure and $\mathrm{BaSO}_{4}$ availability implications for the mineralizing fluids during the Cretaceous period. It is thought that high hydrothermal fluid pressure and sustained $\mathrm{BaSO}_{4}$ availability over a very long time (in millions of years) would produce fairly to very wide mineral veins in sandstone host rocks.

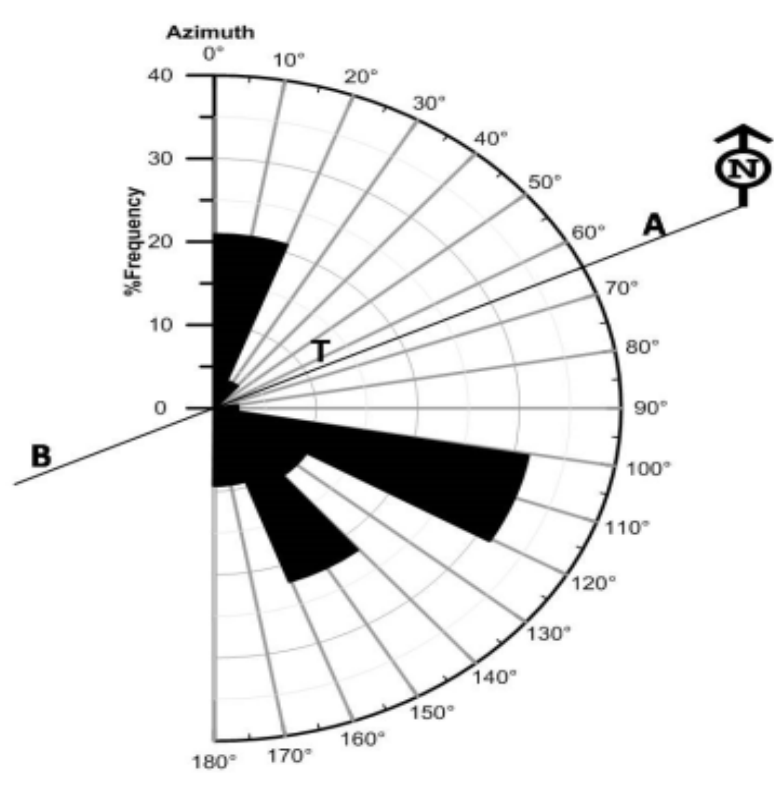

Figure 7. Rose diagram showing the perferred orientations of all known barite veins(86) in the trough. Note the absence of veins in the direction of the Benue Trough Axis BTA 


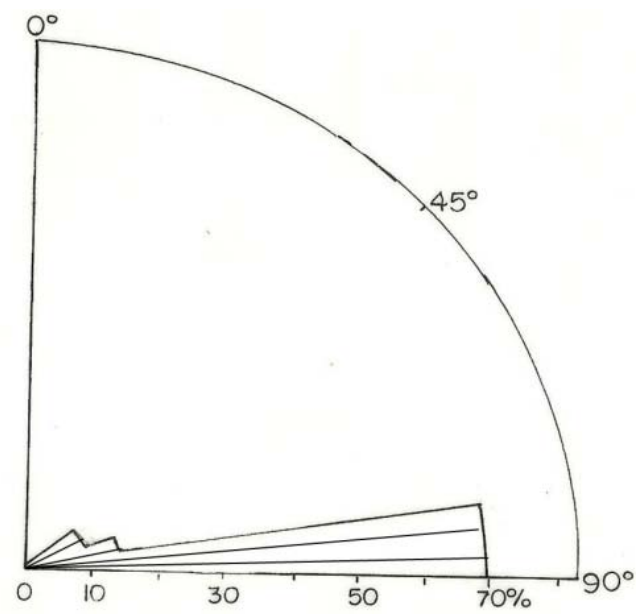

Figure 8. Showing the dips of barite veins in the Benue Trough. Almost $70 \%$ of all measures were between $80^{\circ}$ to $90^{\circ}$ dip. 57 data points

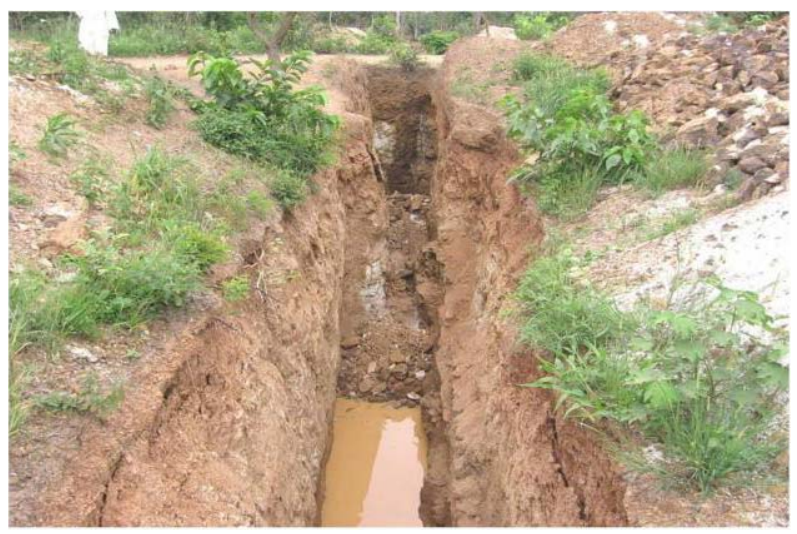

Figure 9. Jobe mine, Seriki Farm, Azara, showing high angle $\left(90^{\circ}\right)$ dip of the vein. High angle dips are typical of barite veins in the trough

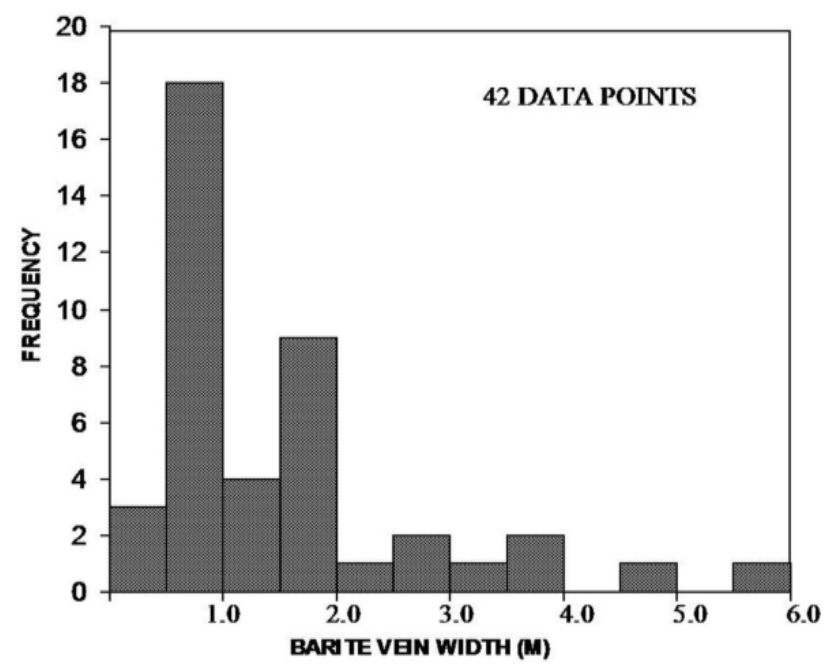

Figure 10. The most frequently occurring vein widths are 0.5 to $1.0 \mathrm{~m}$, though veins up to $6 \mathrm{~m}$ wide were measured 


\subsection{Quality of Barite}

There are currently more than 200 barite sites that have been or are being worked in the Benue Trough alone. The quality of materials varies from field to field and also with depth in a particular mine. Just a few kilometres south of Azara is Ribi. While barite quality has been notoriously poor at Azara, it has been much better at Ribi (Table 2). Also within Lessel area in Ushongo LGA of Benue State, barite quality is higher in Lessel Mbagwa and Lessel Mbato than in Lessel Bunde.

In all cases studied, the quality of material from the top part of a vein $(0-5 \mathrm{~m}$ depth) is always lower than that from the deeper parts of the same vein. That means that much of the touted low quality of Nigerian barite is only so because of the field in question and the level of mining in the veins.

Figure 11 shows the orientations of 29 veins that have been associated with low quality barite. Most of these veins lie in the NW-SE direction, while a few are in the NNE-SSW direction. The poor quality veins, in the NW-SE direction (like Aloshi veins, Azara veins, Bunde Lessel veins, etc), exhibit brecciation and neomineralization. Through these processes new non-barite minerals like quartz, feldspar, siderite, sphalerite, haematite and galena have been included in the barite veins, causing contamination and lowering of quality. On the other hand the few low quality veins with NNE-SSW orientation (Figure 11) are a set of veins in which the barite was deposited originally with a lot of iron ore (haematite).

The possible interpretation of the quality scenario involving the NW-SE veins is that these were the earliest veins to form in the trough, during the first phase of deformation. At this time the maximum principal stress $(\sigma 1)$ was oriented in the NW-SE direction. The second phase of deformation produced veins in the NNE-SSW direction, parallel to the new direction of maximum principal stress $(\sigma 1)$ at that time. This new stress configuration brecciated some of the earlier (NW-SE) veins and the resulting joints were invaded by neomineralization fluids associated with the second phase of deformation. Barite quality is an issue in the Benue Trough, but it is good to point out that not every vein produces poor quality material.

Also several of the veins that produced low quality barite in the first decade of production, when mining was at the top $0-5 \mathrm{~m}$ depth, are now producing higher quality materials at depths of $7-10 \mathrm{~m}$.

\subsection{Associated Minerals}

Barite mineralization in the Benue Trough is associated with quite a range of minerals to varying degrees. While some veins show very little or no associated minerals like Osina-Gabu and Ibi veins, others exhibit half-half associations between barite and galena (Kuduku V-I, Didango). Heavy association with iron ores-haematite, limonite and siderite is common around Azara, Wuse and Kumar (Table 3), affecting the quality of barite coming from there. Apart from this, the popular Vein 17 (Azara field) has a lot of associated quartz. The Aloshi main vein has some galena, a lot of quartz and feldspar, all contributing to the low specific gravity of barite from there. Quartz, siderite/limonite, galena and sphalerite are the main minerals associated with barite around Lessel, south of Gboko. Osina-Gabu mother vein, despite its glassy appearance, magnificent size and quality, still contains fine needles of pyrite and chalcopyrite.

The most pure and unassociated barite in the trough comes from places like Ibi, Ribi, Yandev (Pilla), parts of Osina-Gabu and Chiata.

Table 3. Associated minerals with barite mineralization in the Benue Trough

\begin{tabular}{ll}
\hline Galena/sphalerite & $\begin{array}{l}\text { Kuduku V-I, Didango, Aloshi main vein, Alifokpa, } \\
\text { Lessel }\end{array}$ \\
\hline Quartz & Aloshi, Lessel, Azara V-17, Kuduku V-2 \\
Feldspar & Aloshi \\
Siderite/limonite & Azara (NMC, Jobe Mines), Kumar, Wuse, Lessel \\
Haematite & $\begin{array}{l}\text { Azara (V-1, Jobe Mines, Fugard Mines) } \\
\text { Pyrite/Chalcopyrite }\end{array}$ \\
& $\begin{array}{l}\text { As needles in the glassy barite of Osina/Gabu mother } \\
\text { vein }\end{array}$ \\
\hline
\end{tabular}

\section{Discussion}

In the Benue Trough of Nigeria, barite occurs in vein swarms in about ten fields at the moment. New veins are 
being discovered continuously and some of the earliest known veins are at the stage of utmost production, with good improvement in quality also. Mining at the only two known stratiform, concordant deposits has ceased due to exhaustion of the mineral. The nature of lensoid mineral flats is that they are easier to exhaust through mining than mineral veins, but there may be other levels in the subsurface at no great depth, especially in the vicinity of Alifokpa mine.

The persistence of barite veins in the horizontal and vertical directions, the continuous discovery of new veins in the trough and new fields in contiguous basins are all indicators that locally produced barite has not reached its peak yet. Extensive parts of the trough are yet to be explored and many more veins are likely to be discovered in such places.

NW-SE barite veins are by far more frequent than the N-S or NNE-SSW veins. If fluid pressure remained the same during post-sedimentary deformation in the trough, it could be inferred that the stress configuration that produced the NW-SE veins persisted much longer than and was different from that which produced the NNE-SSW veins.

From high angle nature of the veins, coupled with their tendency to cut across the axes of folds of the two phases of deformation in the trough, it is inferred that these barite veins originated from 'ac' tension or extension joints (Price, 1966; Engelder \& Geiser, 1980). These joints, which form in the 'ac' plane of the tectonic cross, are usually parallel to the maximum principal stress ( $\sigma 1)$ (Rehrig \& Heidrick, 1972; Engelder \& Geiser, 1980), as they are also perpendicular to the fold axes formed with them (Price, 1966).

If barite quality continues to improve with depth as observed, it could be inferred that below about $15 \mathrm{~m}$ of mining depth, no vein might be associated with low quality material again. That would be the end of the low quality stigma associated with Nigerian barite from the trough. For now barite mining should proceed in vertical strips, after stripping of the overburden. This will allow for blending of the less dense top, with the denser bottom material, to form an API grade batch. This applies only to those veins that exhibit vertical quality contrast.

Whether further exploration would reveal more of the $5 \mathrm{~m}$ to $6 \mathrm{~m}$ wide veins is not certain. The only two known in this category are first generation or NW-SE veins, occurring in the Lower Benue Trough. That the majority of the veins sampled are narrow in width and of the 0.5 to $1 \mathrm{~m}$ category, is an indication that the hydrothermal fluids that deposited these veins in the Cretaceous were not highly pressurised and were probably deficient in $\mathrm{BaSO}_{4}$ also. Further evidence of this is seen in the presence of median cavities, which are vein-parallel empty spaces resulting from failure of the sealing phase of the last cycle of the crack-seal mechanism (Ramsay and Huber, 1987).

\section{Summary and Conclusion}

Barite veins in the Benue Trough seem to have their roots in the basement complex beneath the Cretaceous sedimentary cover. The mineralization could therefore be more epigenetic than was earlier thought.

Barite vein orientations are strongly structurally controlled, the most favourable trends being those formed in 'ac' tension or (extension) joints, parallel to the prevailing maximum compressive stress $(\sigma 1)$. Such orientations enable grain growth and vein expansion to take place parallel to the least principal stress $(\sigma 3)-$ a low energy orientation.

The presence of two sets of barite vein trends in the Benue Trough is, as yet, one of the most incontrovertible evidences of two phases of post sedimentary deformations in the trough.

Barite veins tend to come in simple block forms. This makes modelling of the veins at depth easier, just as it facilitates mineral extraction.

The higher incidence of narrow veins over wide ones indicates that hydrothermal fluids were not rich in barium sulphate and were generally of low pressure or low volume in the trough.

More than $95 \%$ of barite occurrences so far seen in the trough are discordant mineral veins. The concordant, stratiform type (mineral flat) is much less frequent, and so far only two sites have been identified.

For large-scale monetization of barite mining in the trough, ten fields have been identified. These include Gombe, Didango, Kumar, Ibi, Azara, Keana, Guma, Lessel, Ihugh and Yala fields.

There are more veins producing medium to high quality barite than those of low quality material, in the trough. If proper batching is practised by oil service companies, there would indeed be no need to import "high grade" barite for blending. 
For those veins that have a quality problem, vertical strip mining is recommended, so as to mix the lower grade material of the top with higher grade barite that invariably comes from below, in order to produce an API grade batch.

The persistence of barite veins into the basement complex implies that barite mining in the trough is going to be a very long-term activity. Also the post-sedimentary compressional tectonics that produced the mineral veins was thick-skinned in nature.

A careful study of the attitude and characteristics of barite veins in the Benue trough has opened a new window by means of which we could understand aspects of the post-sedimentary tectonic history of the trough.

\section{Acknowledgement}

This study was made possible by the Senate Research Grant of the University of Calabar, the Federal Ministry of Solid Mineral Development, through the Nigerian Mineral Appraisal and Monetization Programme (NIMAMOP) and the Sustainable Management of Mineral Resources Project. Dr. Sandra Clark is acknowledged for the set of research papers she sent to the author from the USGS. Dr. Pius Tawo and Mr. Utsu L. Adie are also thanked for their assistance during the NIMAMOP and SMMR projects, respectively.

\section{References}

Baroid invests in barites Jv. (1996). World of Minerals: Industrial Minerals, No. 347, P.14

Benkhelil, J. (1981). On the deformations of the Cretaceous rocks in the Lower Gongola area, Nigeria. J. Min. Geol. 17, 163-169.

Bogue, R. G. (1951). Barite prospect near Gabu, Ogoja Province. G. S. N. Report No. 1014 (unpublished).

Edu, E. E. (2006). Interim report on assessment of barite resources in Taraba State, Nigeria. N.G.S.A Report (unpublished).

Engelder, T., \& Geiser, W. (1980). On the use of regional joint sets as trajectories of palaeostress fields during the development of the Appalachian Plateau, New York. J. Geophys. Res., 85. http://dx.doi.org/10.1029/JB085iB11p06319

Farrington, J. L. (1952). A preliminary description of the Nigerian Lead-Zinc Field. Econ. Geol, 47, 583-608. http://dx.doi.org/10.2113/gsecongeo.47.6.583

Fife, W., Price, N. J., \& Thompson, A. B. (1978). Fluids in the earth's crust. Amsterdam: Elsevier.

Geophysical investigation of barite occurrence around Alifokpa and Gabu, Cross River State, Nigeria. Draft Report, Ministry of Solid Minerals Development, Federal Government of Republic of Nigeria (2005), (unpublished).

Hoque, M. \& Nwajide, C. S. (1984). Tectono-sedimentological evolution of an elongate intracratonic basin (aulacogen): the case of the Benue Trough of Nigeria. J. Min. Geol. 21, 19-25.

McConnell, R. B. (1949b). Notes on the Lead-Zinc deposits of Nigeria and the Cretaceous Stratigraphy of Benue and Cross River Valleys. G.S.N. Report 752, (unpublished).

Minerals and Industry in Nigeria. (1987). Authority of the Government of the Federal Republic of Nigeria, publishers (pp. 42-43)

Offodile, M. E. (1976). The geology of the Middle Benue, Nigeria. Publications from the Palaeontological Inst. Of Univ. Uppsala, Spec. Pub., V4, 166p.

Price, N. J. (1996). Fault and joint development in brittle and semi-brittle rocks. Oxford: Pergamon.

Ramsay, J. G. \& Huber, M. I. (1987). The techniques of modern structural geology. Vol. 2: folds and fractures. London: Academic Press.

Rehrig, W. A. \& Heidrick, T. I. (1972). Regional fracturing in Laramide stocks of Arizona and its relationship to porphyry copper mineralization. Econ. Geol, 67, 198-213. http://dx.doi.org/10.2113/gsecongeo.67.2.198

Report on the detailed drilling of barite vein XVII at Azara, phase 1. Nigerian Mining Corporation, Exploration Division, September 1998 (unpublished).

Tate, R. B. (1959). Memorandum on the barite deposits in the Benue Province. G.S.N. Report. No. 1266, pp. 116-126 (unpublished). 